\title{
KAJIAN FITOKIMIA DAN PROKSIMAT TEPUNG KULIT PISANG Musa sapientum DAN UJI ORGANOLEPTIKNYA PADA DONAT
}

\author{
Phytochemical and Proximate Studies of Musa sapientum Banana Peel Flour and Its \\ Organoleptic Test of Donuts
}

\author{
Titin Aryani, Isnin Aulia Ulfah Mu'awanah, Aji Bagus Widyantara \\ Universitas 'Aisyiyah Yogyakarta \\ E-mail: titinaryanipurnama@gmail.com
}

\begin{abstract}
All types of banana peel can be processed into flour. This study aims to conduct phytochemical and proximate studies of Musa sapientum banana peel flour and its organoleptic test on donuts. The research is quantitative. Phytochemical and proximate profiles were obtained from the results of laboratory tests, while the organoleptic profile of banana skin flour in making donuts was obtained from the results of donut acceptance tests on 60 panelists. The phytochemical profiles examined were antioxidant activity, anthocyanin and carotene levels. The organoleptic profile of Musa sapientum banana peel flour in making donuts examined was taste, color, texture, and aroma. Proximate profiles examined were water, ash, fat, protein, carbohydrate, fiber and yield content. The results showed that the antioxidant activity of Musa sapientum banana peel flour was 61.26 percent, anthocyanin levels $15.62 \mathrm{mg} / 100 \mathrm{~g}$, carotene $136.61 \mathrm{ppm}$, water content 6.92, ash content 1.89 percent, fat content 2.82 percent, protein content 5.31 percent, carbohydrate content 73.98 percent, fiber content 40.58 percent and yield $\mathbf{4 0 . 0 5}$ percent. Organoleptic profile of Musa sapientum donut banana flour with 25 percent of banana peel flour substituent on a scale of 1-5, taste parameters obtained values of 4.37 , color 3.36, texture 3.54, aroma 3.68. The conclusion of the research is donuts made from Musa sapientum banana peel flour with 25 percent substituents of banana peel flour having a relatively good phytochemicals, proximate and organoleptic profile on donuts.
\end{abstract}

Keywords: flour, banana peel, donut

\section{ABSTRAK}

Pada dasarnya, semua jenis kulit pisang dapat diolah menjadi tepung. Penelitian ini bertujuan untuk melakukan kajian fitokimia dan proksimat tepung kulit pisang Musa sapientum dan uji organoleptiknya pada donat. Penelitian ini merupakan penelitian kuantitatif. Profil fitokimia dan proksimat diperoleh dari hasil pemeriksaan laboratorium, sedangkan profil organoleptik tepung kulit pisang pada pembuatan donat diperoleh dari hasil uji daya terima donat terhadap 60 orang panelis. Profil fitokimia yang diperiksa adalah aktivitas antioksidan, kadar antosianin dan karoten. Profil organoleptik tepung kulit pisang Musa sapientum pada pembuatan donat yang diperiksa adalah rasa, warna, tekstur dan aroma. Profil proksimat yang diperiksa adalah kadar air, abu, lemak, protein, karbohidrat, serat dan rendemen. Hasil penelitian menunjukkan bahwa aktivitas antioksidan tepung kulit pisang Musa sapientum sebanyak 61,26 persen, kadar antosianin 15,62 mg/100g, karoten 136,61 ppm, kadar air 6,92, kadar abu 1,89 persen, kadar lemak 2,82 persen, kadar protein 5,31 persen, kadar karbohidrat 73,98 persen, kadar serat 40,58 persen dan rendemen 40,05 persen. Profil organoleptik tepung kulit pisang Musa sapientum donat dengan substituen tepung kulit pisang sebanyak 25 persen pada skala 1-5, parameter rasa memperoleh nilai yaitu 4,37 , warna 3.36, tekstur 3,54, aroma 3,68. Kesimpulan penelitian adalah donat berbahan dasar tepung kulit pisang Musa sapientum dengan subtituen 25 persen tepung kulit pisang memiliki profil fitokimia, proksimat dan organoleptik yang relatif baik pada donat.

Kata kunci: tepung, kulit pisang, donat 


\section{PENDAHULUAN}

B uah merupakan makanan yang memiliki banyak manfaat bagi kesehatan. Buah dan kulit buah dikenal banyak mengandung zat gizi, baik zat gizi makro seperti protein, lemak dan karbohidart, maupun zat gizi mikro, seperti vitamin dan mineral. Disamping itu, pada beberapa kulit buah juga ditemukan mengandung aktioksidan. Selain mengandung antioksidan, rata-rata kulit buah juga memiliki kandungan yang bermanfaat bagi kesehatan seperti kadar serat yang tinggi. ${ }^{1}$

Kulit pisang mengandung serat pangan dalam jumlah $50 \mathrm{~g} / 100 \mathrm{~g}$, merupakan sumber serat pangan potensial. ${ }^{2}$ serat pangan atau dietary fiber adalah karbohidrat (polisakarida) dan lignin yang tidak dapat dihidrolisis oleh enzim pencernaan manusia, dan akan sampai di usus besar (kolon) dalam keadaan utuh sehingga kebanyakan akan menjadi substrat untuk fermentasi bagi bakteri yang hidup di kolon. ${ }^{3}$ Melihat kondisi tersebut, dapat dilakukan suatu solusi alternatif untuk mengolah limbah kulit pisang agar dapat menjadi suatu produk yang bermanfaat. Salah satunya adalah dengan menjadikan kulit buah pisang tersebut menjadi tepung yang kemudian dapat digunakan sebagai bahan baku dalam pembuatan kue donat.

Kulit pisang merupakan salah satu buah yang memiliki potensi besar untuk diolah menjadi tepung substituent terigu, mengingat kandungan karbohidratnya yang cukup besar. Tepung kulit pisang merupakan suatu sumber yang sangat prospektif dalam pengembangan pangan yaitu sebagai sumber makanan baru yang memiliki beberapa keunggulan. Kulit pisang mengandung serat yang cukup tinggi, vitamin C, B, kalsium, protein, dan karbohidrat.

Pada dasarnya, semua jenis kulit pisang dapat diolah menjadi tepung, namun yang terbaik adalah kulit Pisang Raja atau Musa sapientum karena memiliki struktur serat yang lebih tebal dan memiliki kandungan kalsium yang cukup tinggi. ${ }^{4}$ Tepung kulit pisang dapat diaplikasikan pada pembuatan donut. Saat ini, donat merupakan salah satu kue populer favorit masyarakat dunia. Bahkan di Amerika sendiri, saat ini lebih dari 10 juta donat diproduksi setiap tahun. ${ }^{5}$ Sehingga diharapkan dengan penambahan tepung kulit pisang, diharapkan dapat memperbaiki kandungan gizi donat terutama kandungan vitamin dan mineralnya. Selain itu, masyarakat dapat mengurangi ketergantungan terhadap tepung terigu yang merupakan bahan impor dan menduduki porsi terbesar dalam pembuatan donat.

Efektivitas pengolahan kulit pisang menjadi tepung kulit pisang dan aplikasinya dalam pembuatan donat dipandang sangat diperlukan. Efektifitas dapat dinilai dari profil fitokimia, profil proksimat dan profil organoleptik dari tepung kulit pisang Musa sapientum pada pembuatan donut. Sehingga, perlu dilakukan penelitian mengenai profil fitokimia, profil proksimat, dan organoleptic tepung kulit pisang. Tujuan penelitian ini adalah untuk melakukan kajian terhadap fitokimia dan proksimat tepung kulit pisang musa sapientum dan uji organoleptiknya pada donat

\section{METODE PENELITIAN}

Metode penelitian yang digunakan adalah metode analisis kuantitatif. Profil fitokimia dan proksimat diperoleh dari hasil analisis laboratorium, sedangkan profil organoleptik yang diteliti pada pembuatan tepung kulit pisang pada pembuatan donat adalah uji daya terima donat terhadap 60 orang panelis. Profil fitokimia yang dianalisis adalah aktivitas antioksidan, kadar antosianin dan karoten. Profil organoleptik tepung kulit pisang Musa sapientum yang dianalisis pada pembuatan donat adalah rasa, warna, tekstur dan aroma.

\section{Koleksi Sampel Kulit Pisang}

Varian kulit buah pisang yang digunakan dalam penelitian ini adalah kulit pisang raja. Kulit pisang diperoleh dari limbah pedagangpedagang gorengan pisang serta limbah kulit pisang dari konsumsi rumah tangga. Kriteria limbah kulit pisang yang digunakan adalah limbah pisang yang masih baru (belum ada 1 jam dari perlakuan), bersih, dan segera di preparasi untuk pembuatan tepung. Homogenisasi sampel dilakukan dengan cara mencampurkan seluruh sampel yang diperoleh untuk pembuatn tepung.

\section{Pembuatan Tepung Kulit Pisang}


Pembuatan tepung kulit pisang dimulai dengan cara memotong kulit pisang kecil-kecil dengan ukuran kurang lebih $1 \mathrm{~cm} \times 0,5 \mathrm{~cm}$ dengan pisau atau alat pengiris. Kemudian merendam kulit pisang dalam larutan natrium tiosulfat $5 \%$ dan garam $\mathrm{NaCl} 15 \%$ selama 1 jam, setelah itu ditiriskan. Proses pengolahan tepung kulit buah dimulai dari pengeringan kulit menggunakan oven $60^{\circ} \mathrm{C}$ selama 6 jam sampai kulit menjadi benar-benar kering sehingga hasil akhir yang didapat berupa tepung yang kering. Setelah kering atau kadar air kurang lebih 14 persen, potongan kulit buah dapat digiling/dihancurkan dengan menggunakan hammer mill atau ditumbuk. Hasil penggilingan kemudian diayak. Tepung kulit buah yang lolos dari ayakan dikemas dalam kantong plastik. ${ }^{6}$

\section{Analisis Proksimat dan Fitokimia Tepung Kulit Pisang}

Analisis proksimat meliputi kadar karbohidrat, kadar protein, kadar lemak, kadar air dan kadar abu. Sedangkan analisis fitokimia yang akan dilakukan meliputi analisis flavonoid, karoten dan antosianin. Analisis proksimat dan fitokimia dilakukan oleh tenaga ahli di Laboratorium Teknologi Pangan Dan Hasil Pertanian UGM dan di Laboratorium Analisis Makanan dan Minuman Universitas 'Aisyiyah Yogyakarta. Analisis proksimat meliputi kadar air, kadar karbohidrat, kadar protein, kadar lemak, kadar serat dan kadar abu. Analisis ini menggunakan metode AOAC Official Method 2005. Metode yang digunakan dalam penentuan aktivitas antioksidan adalah metode DPPH (Gaulejac dalam (Kiay, 2011). ${ }^{7}$ Penentuan antosianin total dan karoten dilakukan dengan metode Lee, J. 2005. ${ }^{8}$

\section{Pembuatan Donat dari Tepung Kulit Pisang}

Setelah tepung kulit pisang berhasil dibuat, tepung tersebut kemudian digunakan sebagai bahan dasar donat. Tepung kulit pisang kemudian digunakan sebagai bahan substituent tepung terigu dengan perbandingan tepung terigu dan tepung kulit pisang sebanyak 3:1. Pada penelitian ini hanya digunakan 1 formulasi. Bahan-bahan yang digunakan adalah 225 gram tepung terigu protein tinggi, 75 gram tepung kulit pisang, 100 gram kentang kukus yang sudah dihaluskan, 30 gram gula pasir, 1,5 sendok teh ragi instan, 10 gram susu kental manis, 1 butir telur, 150 mililiter air es, 30 gram margarin, 1 sendok teh garam, minyak sayur serta margarin dan coklat meises sebagai toping.

Proses pembuatan donat berbahan dasar tepung kulit pisang dimulai dengan : 1) mencampurkan tepung terigu, kentang, gula pasir, ragi instan dan susu bubuk. Kemudian mengaduk adonan hingga rata. 2) menambahkan adonan dengan telur dan air es sedikit-sedikit diaduk hingga halus. 3) memasukkan margarin dan garam dan mengaduk kembali adonan hingga halus. 4) mendiamkan selama 15 menit. 5) memipihkan adonan hingga masing-masing berbobot sekitar 15 gram, kemudian membulatkan hingga bentuk donat. 6) meletakkan adonan di loyang yang sudah ditaburi tepung terigu dan diamkan hingga adonan mengembang selama 45 menit. 7) menggoreng adonan, mengangkat dan mendinginkan. 8) mengolesi salah satu sisi donat dengan mentega dan menaburi dengan coklat meises.

\section{Uji Organoleptik Tepung Kulit Pisang pada Pembuatan Donat}

Uji organoleptik tepung kulit pisang pada pembuatan donat merupakan metode untuk menilai daya terima produk tepung kulit pisang berdasarkan uji kesukaan oleh panelis (responden). Panelis yang dipilih merupakan civitas akademika dan masyarakat di lingkungan Universitas 'Aisyiyah Yogyakarta. uji organoleptik pada penelitian ini menggunakan 4 skala penilaian yang dilakukan terhadap atribut warna, aroma, rasa, tekstur. Skala penilaian uji hedonik yang digunakan terdiri dari lima skala, yaitu 1 (sangat tidak suka), 2 (tidak suka), 3 (biasa), 4 (suka), 5 (sangat suka).

\section{HASIL}

\section{Karakteristik Fisik Tepung Kulit Pisang Musa sapientum}

Karakteristik fisik tepung kulit pisang yang dianalisis pada penelitian ditampilkan pada Tabel 1. 
Tabel 1

Karakteristik Fisik Tepung Kulit Pisang Raja

\begin{tabular}{ll}
\hline Parameter & Hasil \\
\hline Bentuk & Serbuk \\
Bau & Normal (khas pisang) \\
Rasa & Sedikit getir \\
Warna & Coklat \\
\hline
\end{tabular}

Tabel 2

Data Hasil Analisis Fitokimia Tepung Kulit Pisang Raja

\begin{tabular}{lccc}
\hline \multirow{2}{*}{ Jenis Analisis (satuan) } & \multicolumn{2}{c}{ Hasil Analisis } & Rata-rata Hasil \\
\cline { 2 - 3 } & Ulangan 1 & Ulangan 2 & Analisis \\
\hline Aktifitas Antioksidan, DPPH (\%) & 61,58 & 60,94 & 61,26 \\
Antosianin (mg/100g) & 15,51 & 15,72 & 15,62 \\
Karoten (ppm) & 136,42 & 138,80 & 136,61 \\
\hline
\end{tabular}

Tabel 3

Data Hasil Analisis Proksimat Tepung Kulit Pisang

\begin{tabular}{lccc}
\hline \multirow{2}{*}{ Jenis Analisis } & \multicolumn{2}{c}{ Hasil Analisis } & Nilai Rata-rata \\
\cline { 2 - 3 } & Ulangan 1 & Ulangan 2 & Hasil Analisis \\
\hline Kadar Air (\%) & 6,99 & 6,84 & 6,92 \\
Kadar Abu (\%) & 1,89 & 1,72 & 1,81 \\
Lemak (\%) & 2,82 & 2,83 & 2,83 \\
Protein & 5,31 & 5,33 & 5,32 \\
Karbohidrat & $73,98 \%$ & 74,28 & 74,13 \\
Serat (\%) & $40,58 \%$ & 40,94 & 40,76 \\
Rendemen (\%) & 40,05 & 40,9 & 40,07 \\
\hline
\end{tabular}

Tabel 4

Rata-rata Hasil Uji Organoleptik Donat Berbahan Dasar Tepung Kulit Pisang Raja dengan Skala 0-5 pada 60 Panelis

\begin{tabular}{lcc}
\hline Parameter Uji & Skor Hasil Pengujian Skala (0-5) & Keterangan \\
\hline Rasa & 4.37 & Sangat suka \\
Warna & 3.36 & Suka \\
Tekstur & 3.54 & Suka \\
Aroma & 3.68 & suka \\
\hline Keterangan: & 0-1: sangat tidak suka, 1-2: kurang suka, 2-3-: biasa, 3-4: suka, 4-5: sangat suka
\end{tabular}

\section{Profil Fitokimia Tepung Kulit Pisang Musa sapientum}

Analisis fitokimia yang dilakukan pada penelitian ini meliputi pengukuran aktivitas antioksidan, antosianin, karoten. Hasil analisis fitokimia tepung kulit pisang ditampilkan pada Tabel 2.
Profil Proksimat Tepung Kulit Pisang Musa Sapientum

Pada penelitian ini diperoleh hasil analisis proksimat (kadar air, abu, lemak, protein, karbohidrat, serat dan rendemen) pada tepung kulit buah pisang yang ditampilkan pada Tabel 3. 


\section{Profil Organoleptik Tepung Kulit Pisang Musa Sapientum}

Hasil uji organoleptik terhadap donat berbahan dasar kulit buah pisang dengan perbandingan tepung terigu:tepung kulit pisang yaitu 3:1 (225:75) atau presentase tepung terigu $75 \%$ dan tepung kulit pisang $25 \%$, pada penelitian ini ditampilkan pada Tabel 4 .

Grafik perbandingan hasil uji organoleptic terhadap donat berbahan dasar tepung terigu tanpa tepung kulit pisang dan donat berbahan dasar substituen tepung kulit pisang 25\% ditampilkan pada Gambar 1.

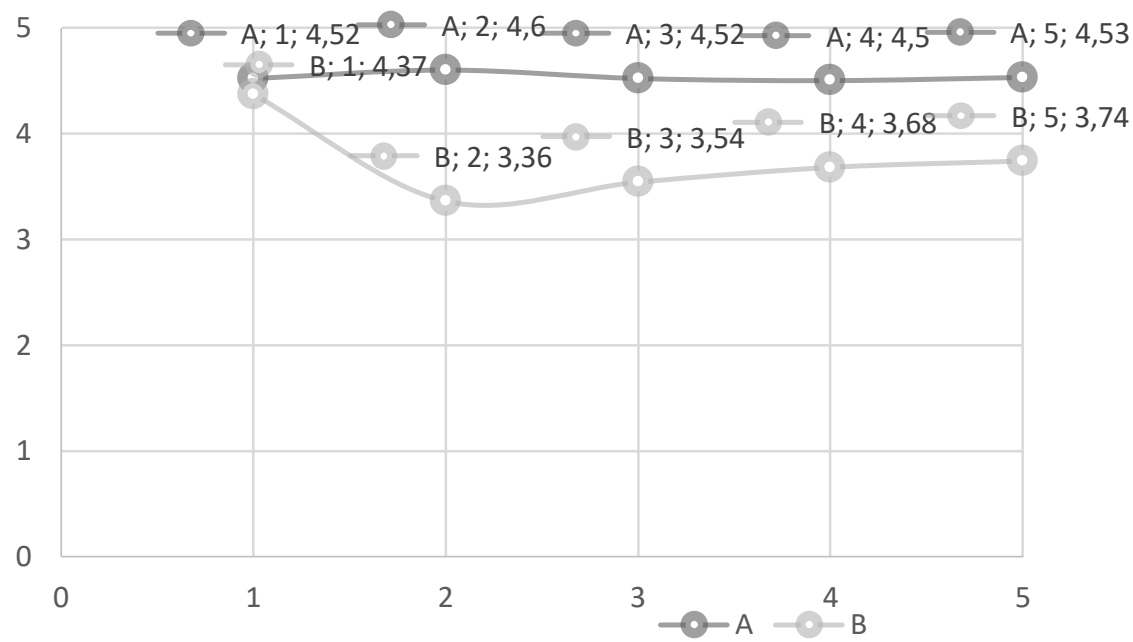

Keterangan :

Pada Sumbu X:

$1=$ Rasa

$2=$ Warna

$3=$ Tekstur

$4=$ Aroma

$5=$ Rasa,

A=Donat Tepung

Terigu Tanpa

Tepung Kulit Pisang

$\mathrm{B}=$ Donat Tepung

Kulit Pisang

$25 \%$

Gambar 1

Grafik Perbandingan Hasil Uji Organoleptic terhadap Donat Berbahan Dasar Tepung Terigu Tanpa Tepung Kulit Pisang dan Donat Berbahan Dasar Substituen Tepung Kulit Pisang 25\%

\section{BAHASAN}

\section{Karakteristik Fisik Tepung Kulit Pisang Musa sapientum}

Karakteristik tepung kulit pisang yang dihasilkan yaitu berberntuk serbuk, berbau normal (khas pisang), memiliki rasa sedikit getir dan berwarna kecoklatan. Warna coklat yang dihasilkan dari tepung pisang merupakan efek dari reaksi browning, baik oleh reaksi enzimatis maupun non enzimatis. Hal ini disebabkan oleh oksidasi dengan udara sehingga terbentuk reaksi pencokelatan oleh pengaruh enzim yang terdapat dalam bahan pangan tersebut (browning enzymatic). Pembentukan warna coklat pada kulit pisang dipicu oleh reaksi oksidasi yang dikatalisis oleh enzim fenol oksidase atau polifenol oksidase. Winarno (2004) juga menambahkan bahwa perendaman dengan larutan garam akan mencegah pencoklatan karena $\mathrm{Na}$ akan berikatan dengan gugus fenol $(-\mathrm{OH})$ sehingga tidak terbentuk senyawa kuinon yang menyebabkan pencoklatan. ${ }^{9}$ Proses pengolahan tepung kulit pisang yang dilakukan mampu menyimpan aroma khas dari pisang, sehingga menghasilkan aroma pisang pada tepung kulit pisang yang dihasilkan. Rasa tepung kulit pisang yang dihasilkan meninggalkan rasa sedikit getir yang mungkin disebabkan oleh residu getah pisang yang belum hilang.

\section{Profil Fitokimia Tepung Kulit Pisang Musa sapientum}

Berdasarkan hasil pengamatan pada penelitian ini diperoleh hasil bahwa aktivitas antioksidan tepung kulit pisang adalah 61,26 \%. Hasil penelitian ini cukup relevan dengan hasil penelitian Fatemeh (2012). Penelitian Fatemeh et al. (2012) yang menguji aktivitas antioksidan dari tepung kulit pisang, didapatkan hasil aktivitas antioksidan sebesar 45,08 $\pm 1,30 \%$ untuk tepung dari kulit matang dan $52,66 \pm 0,82 \%$ untuk tepung dari kulit pisang belum matang (warna hijau). Sedikit perbedaan hasil analisis mungkin disebabkan perbedaan jenis pisang yang dianalisis. ${ }^{10}$ 
Mekanisme penangkal radikal bebas DPPH oleh antioksidan, yaitu berupa donasi proton kepada radikal. Senyawa-senyawa yang memungkinkan mendonasikan protonnya memiliki aktivitas penangkal radikal cukup kuat. Senyawa tersebut adalah golongan fenol, flavonoid tanin, senyawa yang memiliki banyak gugus sulfida dan alkaloid. ${ }^{11}$ Pengujian aktivitas antioksidan pada ekstrak kulit pisang dilakukan pada panjang gelombang maksimum $\mathrm{DPPH} .{ }^{10}$ Adanya aktivitas antioksidan mengakibatkan perubahan warna larutan DPPH dalam methanol yang direaksikan dengan larutan DPPH yang semula ungu (violet) menjadi kuning pucat. Pada penelitian Supriyanti dkk (2015), aktivitas antioksidan pada kulit pisang kapok adalah $95,14 \% .^{13}$

Menurut Robello et. al (2014) ekstrak tepung kulit pisang menunjukkan kandungan fenolik total yang tinggi (sekitar $29 \mathrm{mg} / \mathrm{g}$, sebagai GAE) karena terbentuknya sejumlah besar fenolat flavonoid sebagai prodelphinidin terpolimerisasi (sekitar $3952 \mathrm{mg} / \mathrm{kg}$ ), diikuti dengan penurunan kandungan glikosida flavonol yang lebih rendah (terutama 3rutinosida dan terutama struktur berbasis quercetin, terhitung sekitar $129 \mathrm{mg} / \mathrm{kg}$, B-type procyanidin dimer dan monomeriflavan-3-ol (sekitar $126 \mathrm{mg} / \mathrm{kg}$ ). ${ }^{14}$ Kandungan fenolik total yang tinggi dari ekstrak tepung kulit pisang inilah yang kemungkinan bertanggung jawab atas aktivitas antioksidan yang sangat tinggi.

Selain kadar air, abu dan aktivitas antiokidan, penelitian ini juga menganalisis jumlah antosianin yang ada pada tepung kulit pisang raja. Dari penelitian ini diketahui bahwa kadar antosianin tepung kulit pisang raja adalah $15,61 \%$. Selain berperan sebagai pewarna makanan, antosianin juga dipercaya berperan dalam sistem biologis, termasuk kemampuan sebagai pengikat radikal bebas (free radical scavenging), cardio protective capacity dan kemampuan untuk mengambat tahap inisiasi reaksi kimiawi yang menyebabkan karsinogenesis. ${ }^{15}$

Antosianin dipercaya dapat memberikan manfaat bagi kesehatan manusia. Antosianin ini diketahui dapat diabsorbsi dalam bentuk molekul utuh dalam lambung, ${ }^{16}$ meskipun absorbsinya jauh di bawah $1 \%$, antosianin setelah ditransport ke tempat yang memiliki aktivitas metabolik tinggi memperlihatkan aktivitas sistemik seperti antineoplastik, antikarsinogenik, antiatherogenik, antiviral, dan efek anti-inflammatory, menurunkan permeabilitas dan fragilitas kapiler dan penghambatan agregasi platelet serta immunitas, semua aktivitas ini didasarkan pada peranannya sebagai antioksidan. ${ }^{17,18}$ Antosianin yang tidak terabsorbsi memberikan perlindungan terhadap kanker kolon. ${ }^{19}$ Antosianin banyak ditemukan pada pangan nabati yang berwarna merah, ungu, merah gelap seperti pada beberapa buah, sayur, maupun umbi. Beberapa sumber antosianin telah dilaporkan seperti buah mulberry, bluberry, cherry, blackberry, rosela, kulit dan sari buah anggur, strawberry, lobak merah dan java plum, ${ }^{20}$ namun masih sangat sedikit penelitian tentang sumber antosianin dari bahan lokal terutama kulit buah pisang.

Menurut Fakhrizal dan Yuniar (2016), kulit pisang memiliki kandungan vitamin $A$ sangat tinggi, terutama provitamin $A$, yaitu betakaroten, sebesar $45 \mathrm{mg}$ per 100 gram berat kering. ${ }^{21}$ Beta-karoten tersebut juga berperan sebagai antioksidan. Penelitian Zahera (2012) kulit pisang uli yang diolah menjadi tepung memiliki kandungan beta-karoten sebesar 5,127 $\mathrm{mg} / 100 \mathrm{~g}$. Pada penelitian ini, tepung kulit pisang yang dihasilkan memiliki kadar karoten sebanyak 136,61 ppm ( 13,66 mg/100 gram). ${ }^{22}$ Perbedaan hasil kadar karoten tepung kulit pisang raja dan pisang uli mungkin disebabkan perbedaan jenis kulit pisang yang dianalisis. Sedangkan perbedaan hasil antara kulit pisang dalam penelitian Fakhrizal dan Yuniar (2016) dan tepung kulit pisang pada penelitian ini, selain disebabkan oleh jenis kuli pisang yang dianalisis, mungkin juga disebabkan oleh proses pengolahan. Setelah diolah menjadi tepung, kulit pisang mengalami proses oksidasi sehingga kadar karoten berkurang.

Karoten merupakan bagian dari karotenoid. Karotenoid adalah golongan senyawa kimia organik bernutrisi yang terdapat pada pigmen alami tumbuhan dan hewan. Berdasarkan struktur kimianya, karotenoid masuk ke dalam golongan terpenoid. Karotenoid merupakan suatu zat alami yang sangat penting dan mempunyai sifat larut dalam lemak atau pelarut organik tetapi tidak larut dalam air yang merupakan suatu kelompok pigmen berwarna orange, merah atau kuning (Kurniawan, 2010). ${ }^{23}$ Secara struktural, karotenoid berbentuk rantai hidrokarbon poliena yang kadang-kadang di 
bagian ujungnya terdapat gugus cincin dan mungkin memiliki atom oksigen. Namanya berasal dari kata carotene yang ditambah sufiks -oid, dan berarti senyawa-senyawa sekelompok atau mirip dengan karoten. ${ }^{24}$

Secara keseluruhan kandungan fitokimia tepung kulit pisang raja pada penilitian ini, memiliki aktivitas antioksidan sebanyak 61,26 persen, antosianin sebanyak $15,62 \mathrm{mg} / 100 \mathrm{~g}$, dan karoten sebanyak 136,61 ppm.

\section{Profil Proksimat Tepung Kulit Pisang Musa sapientum}

Kadar air pada penelitian ini menunjukkan bahwa kadar air tepung kulit pisang adalah $6,82 \%$. Pada penelitian Djunaedi (2012) kadar air tepung kulit pisang raja adalah $3,63 \% .^{25}$ Pada penelitian Zahera (2012) kadar bahan kering tepung kulit pisang Uli adalah $80,98 \% .{ }^{21}$ Artinya bahwa tepung kulit pisang Uli memiliki kadar air 9,02\%. Pada penelitian Misriyani (2015), ${ }^{26}$ tepung kulit pisang memiliki kadar air $11,925 \% .{ }^{27}$ Hasil ini relevan dengan penelitian PKKP BKP (2011) yang menyatakan bahwa kadar air pada kulit pisang saat dijadikan tepung harus kurang dari 14\%. ${ }^{6}$ Perbedaan kadar air pada penelitian ini dan penelitian Djunaedi (2012) mungkin disebabkan oleh perbedaan tempat tumbuh buah pisang. Sedangkan perbedaan hasil dengan penelitian Zahera (2012) disebabkan perbedaan jenis kulit pisang yang dianalisis.

Kadar abu tepung kulit pisang pada penelitian menunjukkan kadar yang besar yaitu $1,89 \%$. Hal ini berbeda dengan kadar abu tepung kulit pisang pada penelitian Djunaedi (2012), dimana pada penelitian Djunaedi (2012) diperoleh kadar abu tepung kulit pisang raja sebesar 0,6\%.25 Pada penelitian Hadisoewignyo (2017) diperoleh kadar abu tepung pisang agung sebesar 0,98 $\pm 0,27 \% .{ }^{27}$ Pada penelitian Misriyani (2015) tepung kulit pisang raja memiliki kadar abu sebanyak $7,73 \%{ }^{26}$ Sedangkan SNI tepung terigu mempersyaratkan kadar abu yang baik pada tepung terigu adalah $<0,7 \%$. Artinya bahwa kadar abu tepung kulit pisang pada penelitian ini lebih tinggi dari SNI tepung terigu. Mungkin dapat didefinisikan kadar abu yang terukur pada penelitian ini terlalu tinggi dan tidak memenuhi persyaratan mutu tepung terigu.

Hasil penelitian ini menunjukkan bahwa kadar lemak pada tepung kulit pisang raja adalah sebesar 2,83\%. Hasil penelitian ini berbeda dengan penelitian Djunaedi (2012), Zahera (2012) dan Misriyani (2015). Pada penelitian Djunaedi (2012) kadar tepung kulit pisang raja adalah sebesar $4,26 \% .{ }^{25}$ Pada penelitian Misriyani (2015), kadar lemak pada tepung kulit pisang raja sebanyak 9,45\%, ${ }^{26}$ Sedangkan pada penelitian Zahera (2012) kadar lemak kasar pada tepung kulit pisang uli adalah sebesar $1,18 \% .{ }^{22}$ Pada penelitian Misriyani (2015), kadar lemak tepung kulit pisang raja terukur paling tinggi. ${ }^{26}$ Perbedaan hasil dimungkinkan perbedaan tempat tumbuh buah pisang dan tingkat kematangan atau umur buah yang berbeda serta perbedaan metode analisis yang digunakan.

Kadar protein tepung kulit pisang raja pada penelitian ini adalah 5,31\%. Hasil ini sejalan dengan penelitian Syahruddin (2015). Pada penelitian Syahruddin (2015) kadar protein tepung kulit pisang raja dengan pengeringan oven adalah $5,14 \% .{ }^{28}$ Sedangkan, pada penelitian Djunaedi (2012) kadar protein tepung kulit pisang adalah $8,51 \%$ dan pada penelitian Zahera (2012) kadar protein kasar tepung pisang uli sebanyak $6,76 \%$ serta pada penelitian Misriyani (2015) kadar protein tepung kulit pisang raja adalah 6,25\%,25,22,26 Kadar Protein pada penelitian Djunaedi terukur lebih tinggi. Hal ini mungkin disebabkan perbedaan metode pengukuran kadar protein tepung kulit pisang maupun perbedaan tempat tumbuh buah pisang. Sebab lainnya dapat juga dikarenakan tingkat kematangan dan umur buah yang berbeda.

Hasil pada penelitian ini menunjukkan bahwa kadar karbohidrat tepung kulit pisang rata-rata adalah $74,13 \%$. Menurut Fakhrizal dan Yuniar (2016) kulit pisang mengandung karbohidrat terutama bahan ekstrak tanpa nitrogen sebesar $66,20 \%$ sedangkan pada penelitian Syahrudin (2015) kadar karbohidrat tepung kulit pisang raja yang menggunakan pengeringan oven adalah $57,62 \% .{ }^{22,28}$ Penelitian Djunaedi (2012), kadar karbohidrat tepung kulit pisang raja adalah $82,7 \%$, sedangkan pada penelitian Misriyani (2015) kadar karbohidrat tepung kulit pisang raja sebesar 63,815\%. Perbedaan mungkin disebabkan perbedaan tempat tumbuh buah pisang dan tingkat kematangan dan umur buah pisang yang dianalisis. Hal ini karena, pada penelitian Fakhrizal dan Yuniar (2016) tidak 
disebutkan secara jelas jenis pisang yang dianalisis. Meskipun demikian, kadar karbohidrat pada berbagai penelitian tepung kulit pisang tersebut masih memiliki perbedaan yang relatif sedikit.

Penelitian ini relevan dengan penelitian Emaga et al. (2007) yang menyatakan bahwa kulit pisang mengandung serat pangan dalam jumlah $50 \mathrm{~g} / 100 \mathrm{~g}(50 \%)$. ${ }^{2}$ Tetapi, hasil penelitian ini sedikit lebih rendah. Pada penelitian ini diperoleh kadar serat sebesar $40,76 \%$. Hasil pada penelitian ini hampir sama dengan hasil penelitian Djunaedi (2012) bahwa kadar serat pangan tepung kulit pisang adalah $40,34 \% .{ }^{24}$ Terdapat perbedaan hasil dengan penelitian Emaga et al. (2007). Hal ini mungkin disebabkan karena perbedaan jenis kulit pisang yang dianalisis. Di penelitian Emaga (2007) tidak disebutkan jenis kulit pisang yang dianalisis.

Berdasarkan hasil pengamatan pada penelitian ini, rata-rata rendemen tepung kulit pisang raja pada penelitian ini adalah $40,07 \%$. Hasil ini relevan dengan penelitian Djuneadi (2012). ${ }^{25}$ Pada penelitian Djunaedi dilaporkan bahwa rendemen tepung kulit pisang adalah $41,07 \%$.

\section{Profil Organoleptik Tepung Kulit Pisang Musa sapientum dalam Pembuatan Donat}

Menurut penelitian Alam (2014) menunjukkan bahwa tepung pisang hijau dapat berhasil dimasukkan dalam biskuit tepung terigu hingga 20\% untuk menghasilkan biskuit dengan kualitas dengan atribut sensorik yang dapat diterima. ${ }^{29}$ Menurut penelitian Kahara (2016) uji daya terima substituen tepung kulit pisang raja sebagai pengganti tepung terigu terhadap warna, aroma, rasa, dan tekstur cookies adalah persentase substituen tepung kulit pisang raja $10 \%$ lebih disukai oleh panelis dan tidak terdapat beda nyata dengan persentase substituen $20 \%$ dan $30 \%$. ${ }^{30}$ Pada penelitian ini digunakan presentase substituen tepung kulit pisang sebanyak $25 \%$. Dengan alasan, agar semakin banyak tepung kulit pisang raja yang dapat dimanfaatkan.

Penambahan tepung kulit pisang nampaknya tidak banyak mempengaruhi rasa donat kentang yang merupakan donat favorit masyarakat. Sedangkan penyebab pada parameter warna memperoleh nilai terendah mungkin disebabkan oleh tampilan donat kentang yang terdapat bintik-bintik coklat dari tepung kulit pisang yang kurang enak di pandang. Menurut penelitian Futeri (2014) substituen tepung kulit pisang sebagai pengganti tepung terigu memiliki hasil nilai ratarata uji organoleptik memberikan hasil terbaik untuk warna, aroma, dan rasa donat yaitu pada donat dengan substituen tepung kulit pisang sebanyak $10 \%{ }^{31}$ Hasil penelitian Misriyani (2015) pada aplikasi tepung kulit pisang pada pembuatan muffin, terdapat perbedaan pada aspek aroma, warna dan rasa sedangkan pada aspek tekstur dan permukaan tidak ada perbedaan. ${ }^{26}$ Sampel yang paling disukai masyarakat yaitu pada A (10\% tepung kulit pisang raja) dengan kriteria sangat suka dan memiki kriteria yang sama dengan sampel $\mathrm{K}$ (100\% tepung terigu).

\section{SIMPULAN DAN SARAN}

\section{Simpulan}

Berdasarkan hasil penelitian efektifitas pengolahan limbah kulit pisang raja menjadi donat pada penelitian ini, dapat disimpulkan bahwa kandungan fitokimia tepung kulit pisang Musa sapientum pada penelitian ini, memiliki aktivitas antioksidan 61,26\%, antosianin 15,62 $\mathrm{mg} / 100 \mathrm{~g}$, dan karoten 136,61 ppm. Adapun Kandungan proksimat tepung kulit pisang Musa sapientum pada penelitian adalah lemak 2,83\%, protein $5,32 \%$, karbohidrat $74,13 \%$, serat $40,76 \%$ serta rendemen 40,07\%. Sehingga, Limbah kulit pisang Musa Sapientum relatif efektif untuk diolah menjadi bahan baku pengganti tepung terigu pada pembuatan donat dengan substituen sebanyak $25 \%$.

\section{Saran}

Saran penelitian ini adalah dilakukan variasi subtituen tepung kulit pisang Musa sapientum pada pembuatan donat.

\section{UCAPAN TERIMA KASIH}

Penulis mengucapkan terimakasih kepada Kemenristek DIKTI yang telah mendanai penelitian ini dalam skema Hibah Penelitian Dosen Pemula Tahun Anggaran 2018 dan mahasiswa yang ang telah membantu terselesaikannya penelitian ini. 


\section{RUJUKAN}

1. Aryani, T., Isnin Aulia Ulfah Mu'awanah, Aji Bagus Widyantara. Aplikasi Kulit Pisang Menjadi Tepung: Aktivitas Antioksidan Tepung Kulit Pisang Musa Sapientum. Jurnal Kesehatan Masyarakat. 11(2). 2018: 1015-1020.

2. Emaga, T.H., Andrianaivo, R.H., Wathelet, B. , Tchango, J.T and Paquot, M. Effects of the stage of Maturation and Varieties on the Chemical Composition of Banana and Plantain peels. Food Chemistry. 2007;103 : 590- 600 .

3. Silalahi, Jansen, Hutagalung $\mathrm{N}$. Komponen-komponen Bioaktif dalam Makanan dan Pengaruhnya terhadap Kesehatan. Jurusan Farmasi Universitas SumatraUtara, Medan; 2002.

4. Sukriyadi, 2010. Kajian Sifat Kimia dan Sifat Organoleptik Pada Tepung Kulit Pisang Dari Beberapa Varietas Pisang (Skripsi). Ternate: Universitas Khairun Ternate).

5. Chan LA. Inspirasi Usaha Membuat Aneka Donat. Jakarta (ID): PT AgroMedia Pustaka; 2004.

6. PKKP BKP. Membuat Tepung dari Kulit Pisang. Pusat Penganekaragaman Konsumsi dan Kemanan Pangan Badan Ketahanan Pangan Republik Indonesia. Diakses pada 2 Mei 2018. http://pusatpkkp.bkp.pertanian.go.id/berita-205membuat-tepung-dari-kulitpisang.html; 2018.

7. Kiay, N., E. Suryanto dan L. Mamahit. Efek Lama Perendaman Ekstrak Kalamansi (Citrus microcarpa) terhadap Aktivitas Antioksidan Tepung Pisang Goroho (Musa spp). Chem. Prog. 2011, 4, 27-33.

8. Lee, J. 2005. Determination of Total MonomericAnthocyanin Pigment Content of FruitJuices, Beverages, Natural Colorants, andWines by the $\mathrm{pH}$ Differential Method:Collaborative Study. Journal Of AOAC International, $88(5): 1269$

9. Winarno. Kimia Pangan dan Gizi.
Gramedia Pustaka Utama. Jakarta; 2004.

10. Fatemeh, S. R., Saifullah, R., Abbas, F. M. A. and Azhar, M. E. Total phenolics, flavonoids and antioxidant activity of banana pulp and peel flours: influence of variety and stage of ripeness. International Food Research Journal. 2012; 19 (3): 1041-1046.

11. Munim, A. Antioxidative Compound From Crottalaria Sessiliflora. Biosci Biotech Biochem. 2003; 67,410-414.

12. Garcia, E.J., Tatiane L.C.O, Saverino M.D.A, Alessandra Reis, Alesaandro D.L, Rosa Helena M.G Antioxidant Activity by DPPH Assay of Potential Solutions to be Applied on Bleached Teeth . Brazilian Dental Journal. 2012; 23 (1): 22-27.

13. Supriyanti, FMT, Hokcu Suanda, Riska Rosdiana Pemanfaatan Ekstrak Kulit Pisang Kepok (Musa Bluggoe) sebagai Sumber Antioksidan pada Produksi Tahu. Makalah Pendamping pada Seminar Nasional Kimia dan Pendidikan Kimia VII 18 April 2015. Surakarta : FPMIPA UNS; 2015.

14. Robello, L.P.G., Afonso Mota Ramos, Paula Becker Pertuzatti , Milene Teixeira Barcia ,

15. Noelia Castillo-Muñoz, Isidro Hermosín-Gutiérrez.. 2014. Flour of banana (Musa AAA) peel as a source of antioxidant phenolic compounds. Food Reseach International. 2014; 55: 397-403.

16. Smith M, K. Marley, D. Seigler, K. Singletary \& B. Meline. Bioactive Properties of Wild Blueberry Fruits. Journal of Food Science. 2000; 65:352-356.

17. Passamonti S, U Vrhovsek, A Vanzo \& $F$ Mattivi.The Stomach as a Site For Anthocyanins Absorption From Food. FEBS Letters. 2003; 544:210-213.

18. Clifford, M. N. Anthocyanins- nature, occurrence and dietary burden. Journal of the Science of Food and Agriculture. 2000; 80: 1063-1072.

19. Middleton, E., Kandaswami, C., \& Theoharides, T. C. The effects of plant flavonoids on mammalian cells:implications for inflammation, 
heart disease, and cancer. Pharmacological Reviews. 2000;52: 673-751.

20. Halliwell B, K Zhao dan M. Whiteman. The Gastrointestinal Tract: The Major Site of Antioxidant Action?. Free Radical Research. 2000; 33: 819-830.

21. Ayed Amr dan E. Al-Tamimi. Stability of The Crude Extracts of Ranunculus Asiaticus Anthocyanins and Their Use As Food Colourants. International Journal of Food Science \& Technology. 2007; 42 (8): 985-991.

22. Fakhrizal dan Yuniar. Kombinasi Tepung Kulit Pisang dan Tepung Kulit Ubi Terhadap Kecernaan Bahan Kering dan Bahan Organik pada Ayam Broiler. Jurnal IImiah Peternakan. 2016;4 (2): 8-11.

23. Zahera, R. Pemanfaatan Beta-Karoten dalam Tepung Kulit Pisang sebagai Pengganti Sebagian agung untuk Menghasilkan Telur Ayam Arab Rendah Kolesterol. Skripsi. Bogor : Departemen IImu Nutrisi dan Teknologi Pakan, Fakultas Peternakan, Institut Pertanian Bogor; 2012.

24. Kurniawan, M., Izzati, M., Nurchayati,Y. Kandungan Klorofil, Karotenoid, dan Vitamin C pada Beberapa Spesies Tumbuhan Akautik. Buletin Anatomi dan Fisiologi. 2010; 18(1): 28-40.

25. Ikawati, R. Optimasi Kondisi Ekstraksi Karotenoid Wortel (Daucus carota L.) menggunakan Response Surface Methodology (RSM). Jurnal Teknologi Pertanian. 2005; 1(1): 14-22.

26. Djunaedi, E. Pemanfaatan Limbah Kulit Pisang Sebagai Sumber Pangan Alternatif dalam Pembuatan Cookies. Program Studi Kimia Fakultas Matematika dan IImu Pengetahuan Alam Universitas Pakuan; 2012.
27. Misriyani. 2015. Eksperimen Pembuatan Muffin Substitusi Tepung Kulit Pisang Raja. Skripsi. Semarang : Fakultas Teknik Unnes.

28. Hadisoewignyo L, Foe K., dan Tjandrawinata R.R. Isolation and characterization of Agung Banana peel starch from East Java Indonesia. International Food Research Journal. 2017; 24(3): 1324-1330.

29. Syahruddin AN Irviani A. Ibrahim, Nurdiyanah. Identifikasi Zat Gizi dan Kualitas Tepung Kulit Pisang Raja (Musa Sapientum) dengan Metode Pengeringan Sinar Matahari dan Oven. Media Pangan Indonesia. 2015; 19(1): 116-121.

30. Alam, S.M. Asif UI, M. Z. Islam, M. M. Hoque, K. Monalisa Effects of Drying on the Physicochemical and Functional Properties of Green Banana (Musa sapientum) Flour and Development of Baked Product. American Journal of Food Science and Technology. 2014; 2(4): 128-133.

31. Kahara, G.D. Pengaruh Substitusi Tepung Kulit Pisang Raja terhadap Kadar Serat dan Daya Terima Cookies. Skripsi. Surakarta : UMS; 2016.

32. Futeri, R., Pharmayeni. Substituting Wheat Flour with Banana Skin Flour from Mixture Various Skin Types of Banana on Making Donuts. International Journal on Advanced Science Engineering Information Technology. 2014; 4 (1): 40-44. 